Vol.60: e17160634, January-December 2017 http://dx.doi.org/10.1590/1678-4324-2017160634 ISSN 1678-4324 Online Edition
BRAZILIAN ARCHIVES OF BIOLOGY AND TECHNOLOGY

AN INTERNATIONAL JOURNAL

\title{
Alterations in Biomarkers Associated with Sterility in Pectinophora gossypiella (Saunders) Induced by Gamma Irradiation
}

\author{
Hanaa Mahmoud Ali ${ }^{1,2}$, Hemat Zakaria Moustafa ${ }^{3}$, Rehab Mahmoud Sayed ${ }^{4 *}$. \\ ${ }^{I}$ Department of Genetics and Cytology; National Research Center; Egypt; ${ }^{2}$ Preparatory Year Deanship; King Saud \\ University; Riyadh ? KSA; ${ }^{3}$ Plant Protection Research Institute, Agricultural Research Center, Dokki, Giza, Egypt; \\ ${ }^{4}$ Natural Product Research Department, National Center for Radiation Research and Technology (NCRRT), Atomic \\ Energy Authority, P.O. Box 29 Nasr City, Cairo, Egypt.
}

\begin{abstract}
Nowadays, radiation technology is widely used to produce changes in Biosystems. The goal of this work is to determine the variation induced male Pectinophora gossypiella in gamma-irradiated as pupae using 50Gy and 150Gy. Comparing elements composition and DNA (using RAPD-PCR) between substerile 50Gy and the sterile dose 150Gy in P. gossypiella showed variation between them. Potassium $(K)$ was the most abundant elements in unirradiated and irradiated males followed by magnesium $(\mathrm{Mg})$. The percentage of heavy metals as copper, zinc, and cadmium concurrent with $K$ was directly proportional to the radiation dose. While the percentage of $M g$, Phosphorous and calcium decreased as the radiation dose increased. The results also revealed that some extra bands appeared and others disappeared, as a result of irradiation. The appearance of extra bands may be due to the repair mechanism of the irradiation damaged DNA. The banding patterns obtained and the dendrograms drawn on the basis of presence and absence of bands revealed that 150Gy irradiated pupae are more different from the unirradiated pupae than the 50Gy irradiated pupae. It was concluded that the sterile male technique could be used as a benefit tool in controlling P. gossypiella.
\end{abstract}

Keywords: Pectinophora gossypiella; gamma rays; RAPD-PCR; elements; DNA

\footnotetext{
*Author for correspondence: rehab.omar@yahoo.com, rehab.omar@eaea.org.eg
} 


\section{INTRODUCTION}

Cotton is one of the worldwide essential economic crops. It provides sustenance to farmers, factories, textile workers and earns foreign exchange. The pink bollworm; Pectinophora gossypiella (Saunders) (Lepidoptera: Gelechiidae) has become a real threat to pesticides. It attacks to fruiting bodies of cotton ranges from 20-30 percent ${ }^{1}$. There is an immediate need for simple methods to control this destructive insect. The technique of using ionizing radiation to induce sterility in the $F_{1}$ generation by irradiating the parents is now the most promising genetic method for suppression of lepidopterous population ${ }^{2}$. The irradiation of mature pink bollworm pupae at a dose of 100 or $150 \mathrm{~Gy}$ of gamma radiation indicated that reproduction of irritated males, when confirmed with untreated female moths, was reduced by $88 \%$ or more in $\mathrm{F}_{1}$ progeny ${ }^{3}$.

Metals play an important role in the maintenance of biological, biochemical and physiological pathways, so insects concentrate metals in their tissues. This assemblage in insects differs from one species to another and from one metal to another ${ }^{4}$. The major and trace elements are vital to the insect to sustain an ionic balance suitable to the activity of insect, as cofactors of some enzyme systems ${ }^{5}$. ElShall ${ }^{6}$ on Spodoptera littoralis mentioned that the disturbance in elemental metabolism due to irradiation may play an indirect role in the sterility phenomenon since several elements have an essential function as activators and/or coenzymes for many of the enzymatic reactions which control certain physiological processes.

Insect sterilization through induction of dominant lethal mutation in the genetic material results from the exposure to ionizing radiation (IR) ${ }^{7}$. A major source of the mutation load in living organisms is the oxidative DNA damages, with more than one hundred oxidative DNA adducts ${ }^{8}$.

Recently, several selective and sensitive assays developed, such as restriction fragment length polymorphism, quantitative traits loci, random amplified polymorphic DNA (RAPD), amplified fragment length polymorphisms, simple sequence repeat, variable number of tandem repeats for DNA analysis in ecogenotoxicology as a result of the advances in molecular biology ${ }^{9}$. RAPD-PCR is one of the most feasible methods or techniques used for detection of DNA damage and mutations comparing DNA fingerprints from untreated and treated samples ${ }^{10,11}$.

Previous studies have shown the biochemical and biological effect of gamma radiation doses (100 and 150 Gray) on $F_{1}$ adult male and female almond moths, Ephestia cautella (Walker) (Pyralidae: Lepidoptera) descendant of irradiated parental male pupae ${ }^{12}$, and the variation induced in elemental contents in the body tissues of Galleria mellonella adult males and females parents irradiated with 50 and 150 Gy and their $F_{1}$ generation ${ }^{13}$.

The present study aimed to investigate the alterations of element concentrations and DNA pattern in male $P$. gossypiella related with irradiation of mature pupae with substerile and sterile dose (50 and 150Gy) in order to establish radiation as a control tool.

\section{MATERIALS AND METHODS}

\section{Insect Rearing}

The pink bollworm, Pectinophora gossypiella were obtained from Bollworms Research Department, Plant Protection Research Institute, Dokki, Giza, Egypt. It reared to several generations on modified artificial diet as described by Abd El- 
Effect of gamma radiation on the pink bollworm

Hafez et al. ${ }^{14}$ under laboratory controlled conditions at $27+1{ }^{\circ} \mathrm{C}$ and $75+5 \%$ R.H.

\section{Irradiation process}

Full-grown pupae were gamma irradiated with sub sterilizing and sterilizing doses (50 Gy and 150 Gy, respectively), using $\mathrm{Co}^{60}$ gamma irradiation unit located at National Center for Radiation Research and Technology, Cairo, Egypt. The dose rate was $1.774 \mathrm{KGy} / \mathrm{h}$. at the time of the present investigation.

\section{Preparation and analysis of Metal (mineral) percent}

Newly emerged males of unirradiated and irradiated pupae were oven dried, defatted and analyzed by Energy Dispersive X- ray analyzer (EDX), this analyzer attached to Scanning Electron Microscope (SEM) model HEOL- JSM 4500. The program software used is OXFORED- ISIS under windows. The EDX constituent is; X-ray detector, multichannel analyzer and a programmed computer with X-ray analysis software. X-ray is emitted from the samples surface when bombarded with an electron beam. From this analysis, we can determine the kinds of elements exist in the adults' body and the percentage of each metal. Five replicates were conducted for each radiation doses and control ${ }^{13}$.

\section{DNA extraction and RAPD-PCR}

Unirradiated and irradiated adults were ground using a mortar and pestle with liquid nitrogen. Extraction and purification of samples were carried out using DNeasy mini spin columns as described by by the manufacturer (Qiagene, Hilden, Germany) and stored at $-80^{\circ} \mathrm{C}$. RAPD-PCR reaction was performed according to the protocol of Williams et al. ${ }^{15}$. Reactions were performed in a total volume $50 \mu \mathrm{L}$ reaction buffer (100mMKcL, Tris HCL ph 8.3) $3 \mathrm{mM} \mathrm{MgCl}_{2}, 150$ mMdNTPs (Promega Biotech. Inc.), 50p/mole primers and $1 \mu \mathrm{Taq}$ polymerase (obtained from Operon Technologies). This reaction was added to $0.1 \mu 1$ genomic DNA. Tubes containing mixes were placed in a thermocycler (Perkin -Elmer 2400) and DNA was amplified using the following temperature profile modified from Black et al. ${ }^{16}$. Eight arbitrary primers were used, 4 of them only gave polymorphism with the samples (Table 1). Amplification was carried out for 40 cycles after initial denaturation for $4 \mathrm{~min}$ at $94^{\circ} \mathrm{C}$. Each cycle consisted of denaturation at $94^{\circ} \mathrm{C}$ for $1 \mathrm{~min}$; annealing at $36^{\circ} \mathrm{C}$ for $1 \mathrm{~min}$; extension at $72^{\circ} \mathrm{C}$ for $1 \mathrm{~min}$ and final extension at $72^{\circ} \mathrm{C}$ for $10 \mathrm{~min}$. After the reaction, the mixture was mixed with DNA loading buffer and electrophoresed on $1 \%$ Agarose gel. Using 250pb DNA ladder, the lengths of the different DNA fragments were determined. The electrophoresis gel images were recorded using a gel Documentation system (UVP, UK). RAPD fragments and lane matching were scored as present/absent band using gel analyzer program CLIQS 1D Pro (Totallab). Bands in each treatment were compared using the similarity index formula of Nei and $\mathrm{Li}$ (1979) which reflects the extent of band sharing between individuals.

Table 1: The nucleotide sequences of the primers used for RAPD-PCR analysis.

\begin{tabular}{|c|c|}
\hline Primer name & Sequence $\left(5-3{ }^{`}\right)$ \\
\hline V12 & ACCCCCCACT \\
U10 & ACCTCGGCAC \\
E2 & GGTGCGGGAA \\
A1 & CAGGCCCTTC \\
\hline
\end{tabular}




\section{Statistical Analysis:}

The data of the elements composition were analyzed by one-way analysis of variance (ANOVA) followed by Dunnett's multiple ranges to compare different group means, using SPSS statistic program (version 20).

\section{RESULTS}

Elements composition percentage of Pectinophora gossypiella adult males resulted from irradiated pupae with sub sterilizing and sterilizing doses compared with control are shown in table 2.

Table 2: Percentage of element composition of $P$. gossypiella adult males after irradiating pupae with sub sterilizing and sterilizing doses.

\begin{tabular}{|l|c|c|c|}
\hline \multirow{2}{*}{\multicolumn{1}{c|}{ Element }} & \multicolumn{3}{|c|}{$\begin{array}{c}\text { Percent Composition } \\
\text { Gamma Radiation Doses }\end{array}$} \\
\cline { 3 - 4 } & \multirow{2}{*}{ Control } & $50 \mathrm{~Gy}$ & $150 \mathrm{~Gy}$ \\
\hline Magnesium (Mg) & $20.12 \pm 1.14$ & $15.76 \pm 1.9^{*}$ & $12.56 \pm 0.63^{* \mathrm{a}}$ \\
Phosphorus (P) & $14.58 \pm 1.25$ & $14.15 \pm 0.89$ & $12.50 \pm 1.46^{*}$ \\
Potassium (K) & $26.25 \pm 1.77$ & $28.51 \pm 0.99$ & $29.10 \pm 1.47$ \\
Calcium $(\mathrm{Ca})$ & $15.12 \pm 1.82$ & $10.78 \pm 1.62$ & $7.65 \pm 0.42^{* \mathrm{a}}$ \\
Copper $(\mathrm{Cu})$ & $9.93 \pm 1.45$ & $14.27 \pm 1.21$ & $17.56 \pm 2.1^{\mathrm{a}}$ \\
Zinc $(\mathrm{Zn})$ & $7.32 \pm 1.3^{*}$ & $9.59 \pm 1.6$ & $12.15 \pm 1.2$ \\
Cadmium $(\mathrm{Cd})$ & $6.68 \pm 0.66^{*}$ & $7.18 \pm 0.57$ & $8.48 \pm 0.36$ \\
\multicolumn{1}{|c|}{ H.M $(\mathrm{Cu}, \mathrm{Zn}, \mathrm{Cd})$} & $23.93 \pm 3.41$ & $30.8 \pm 3.38$ & $38.19 \pm 3.69$ \\
\hline
\end{tabular}

$*=<2$ Sigma, H.M = Heavy Metals

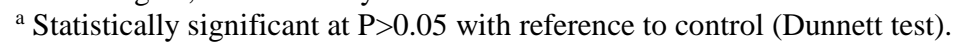

Potassium was the most abundant element in control adults and represented by $26.25 \%$. The relative percentage of $(\mathrm{K})$ slightly increased in adults when treated with 50 and 150 Gy doses to reach 28.5 and $29.1 \%$, respectively. Irradiation with 50 and 150 Gy showed also a significant decrease in the relative percentage of $\mathrm{Mg}$ that reached 15.76 and $12.56 \%$, respectively.

Phosphorous (P) percentage recorded $14.58 \%$ in unirradiated control; this percentage showed a slight decrease at the treatments of 50 and 150 Gy reaching 14.15 and $12.5 \%$, respectively.

Calcium (Ca) represented $15.12 \%$ in tissues of a control sample, this percentage slightly decreased to reach 10.78 and $7.65 \%$ in tissues of samples irradiated with 50 and $150 \mathrm{~Gy}$.

Copper $(\mathrm{Cu})$ represented $9.93 \%$ in control sample then increased to $14.27 \%$ in samples irradiated with $50 \mathrm{~Gy}$, and it increased significantly to $17.56 \%$ when samples were irradiated with $150 \mathrm{~Gy}$.

The percentage of zinc $(\mathrm{Zn})$ in unirradiated sample reached $7.32 \%$ then increased slightly to 9.59 and $12.15 \%$ in samples irradiated with 50 and $150 \mathrm{~Gy}$, respectively. The Cadmium $(\mathrm{Cd})$ percentage recorded was $6.68 \%$ in control; this percentage showed a slight increase when treated with 50 and 150 Gy to reach 7.18 and $8.48 \%$, respectively. Also, the percentage of the heavy metals increased as the radiation dose increased.

Evaluation of DNA changes between control and irradiated samples of $P$. gossypiella adult males:

Numbers of polymorphic and monomorphic bands of the different treatments with the four random primers are shown in table 3 . 
Effect of gamma radiation on the pink bollworm

Table 3: Numbers of polymorphic and monomorphic bands of the different treatments of $P$. gossypiella adult males with the four random primers.

\begin{tabular}{|c|c|c|c|c|}
\hline Primer & Polymorphic bands & Monomorphic bands & Total & \%Polymorphism \\
\hline V12 & 6 & 1 & 7 & 85.7 \\
U10 & 3 & 2 & 5 & 60 \\
E2 & 2 & 2 & 4 & 50 \\
A1 & 5 & 1 & 6 & 83.3 \\
\hline Total & 16 & 6 & 22 & \\
\hline
\end{tabular}

RAPD analysis of the extracted DNA samples of $P$. gossypiella adults using a V12 primer indicated the presence or absence of polymorphic bands with Molecular size (MS) 2955, 2239, 1692, 1143, 650, 457, and 280 (table 4). The first and second bands were present in $P$. gossypiella control adults only. The third and sixth bands were observed in both of the control and group irradiated with 50Gy. The fourth band was the monomorphic one. The fifth and the seventh bands appeared only in the group irradiated with 150Gy.

Results in table 4 showed the RAPD markers using U10 primer indicated the presence or absence of polymorphic bands with MS 1310, 781, 548, 367, and 287. The first band appeared in control group only. The second and third bands were absent in irradiated group with 150Gy. The fourth and fifth bands were monomorphic bands.

Table 4: Detection of DNA polymorphism using RAPD-PCR with four primers for unirradiated and irradiated $P$. gossypiella adult males:

\begin{tabular}{|c|c|c|c|c|}
\hline Band No. & $\begin{array}{c}\text { Molecular } \\
\text { size (bp) }\end{array}$ & Control & $50 G y$ & 150Gy \\
\hline \multicolumn{5}{|c|}{ V12 } \\
\hline 1. & 2955 & $\mathrm{x}$ & - & - \\
\hline 2. & 2239 & $\mathrm{x}$ & - & - \\
\hline 3. & 1692 & $\mathrm{x}$ & $\mathrm{x}$ & - \\
\hline 4. & 1143 & $\mathrm{x}$ & $\mathrm{x}$ & $\mathrm{x}$ \\
\hline 5. & 650 & - & - & $\mathrm{x}$ \\
\hline 6. & 457 & $\mathrm{x}$ & $\mathrm{x}$ & - \\
\hline 7. & 280 & - & - & $\mathrm{x}$ \\
\hline \multicolumn{5}{|c|}{ U10 } \\
\hline 1. & 1310 & $\mathrm{x}$ & - & - \\
\hline 2. & 781 & $\mathrm{x}$ & $\mathrm{x}$ & - \\
\hline 3. & 548 & $\mathrm{x}$ & $\mathrm{x}$ & - \\
\hline 4. & 376 & $\mathrm{x}$ & $\mathrm{x}$ & $\mathrm{x}$ \\
\hline 5. & 287 & $\mathrm{X}$ & $\mathrm{x}$ & $\mathrm{x}$ \\
\hline \multicolumn{5}{|c|}{ E2 } \\
\hline 1. & 2827 & $\mathrm{x}$ & $\mathrm{x}$ & $\mathrm{x}$ \\
\hline 2. & 1638 & $\mathrm{x}$ & $\mathrm{x}$ & $\mathrm{x}$ \\
\hline 3. & 1425 & $\mathrm{x}$ & $\mathrm{x}$ & - \\
\hline 4. & 1045 & - & $\mathrm{x}$ & - \\
\hline \multicolumn{5}{|c|}{ A1 } \\
\hline 1. & 2873 & - & $\mathrm{x}$ & $\mathrm{x}$ \\
\hline 2. & 1588 & $\mathrm{x}$ & - & $\mathrm{x}$ \\
\hline 3. & 902 & $\mathrm{x}$ & - & - \\
\hline 4. & 679 & - & $\mathrm{x}$ & - \\
\hline 5. & 450 & $\mathrm{x}$ & $\mathrm{x}$ & $\mathrm{x}$ \\
\hline 6. & 312 & $\mathrm{x}$ & $\mathrm{x}$ & - \\
\hline
\end{tabular}

The MS of polymorphic fragments produced by RAPD analysis using E2 primer were $2827,1638,1425$, and 1045 . The first and second bands were monomorphic 
bands. A radiation dose of $150 \mathrm{~Gy}$ caused the absence of the third band. The fourth band appeared only in the group irradiated with 50Gy.

The result of RAPD analysis using A1 primer revealed the presence or absence of polymorphic bands with MS 2873, 1588, 902, 679, 450, and 312. The first band was absent in the control group while the second band was absent in group irradiated with 50Gy. The third band was present in the control but the fourth band was present in 50Gy irradiated groups. The fifth band is the monomorphic one while the sixth band was absent in sample irradiated with 150Gy.

Two bands with MS 2955 and 2239, another band with MS 1310 and one band with MS 902 were found in the control group but disappeared in irradiated ones using V12, U10 and A1 primers, respectively. This may be due that gamma radiation turning off such gene. On the other hand, two bands with MS 650 and 280 appeared in the an group irradiated with 150Gy using V12 primer. Other two bands with MS 1045 and 679 appeared in the group irradiated with 50Gy using E2 and A1 primers, respectively.

Figure (1a) revealed that the control and irradiated sample of DNA produced 5 and 3 fragments, respectively using V12 primer. The five fragments of the control have MS of 2955, 2239, 1692, 1143, and 457, while the MS of the DNA fragments of the group irradiated with 50Gy were 1692, 1143, and 457 such MS of the DNA fragments of the group with irradiated 150Gy were1143, 650, and 280.
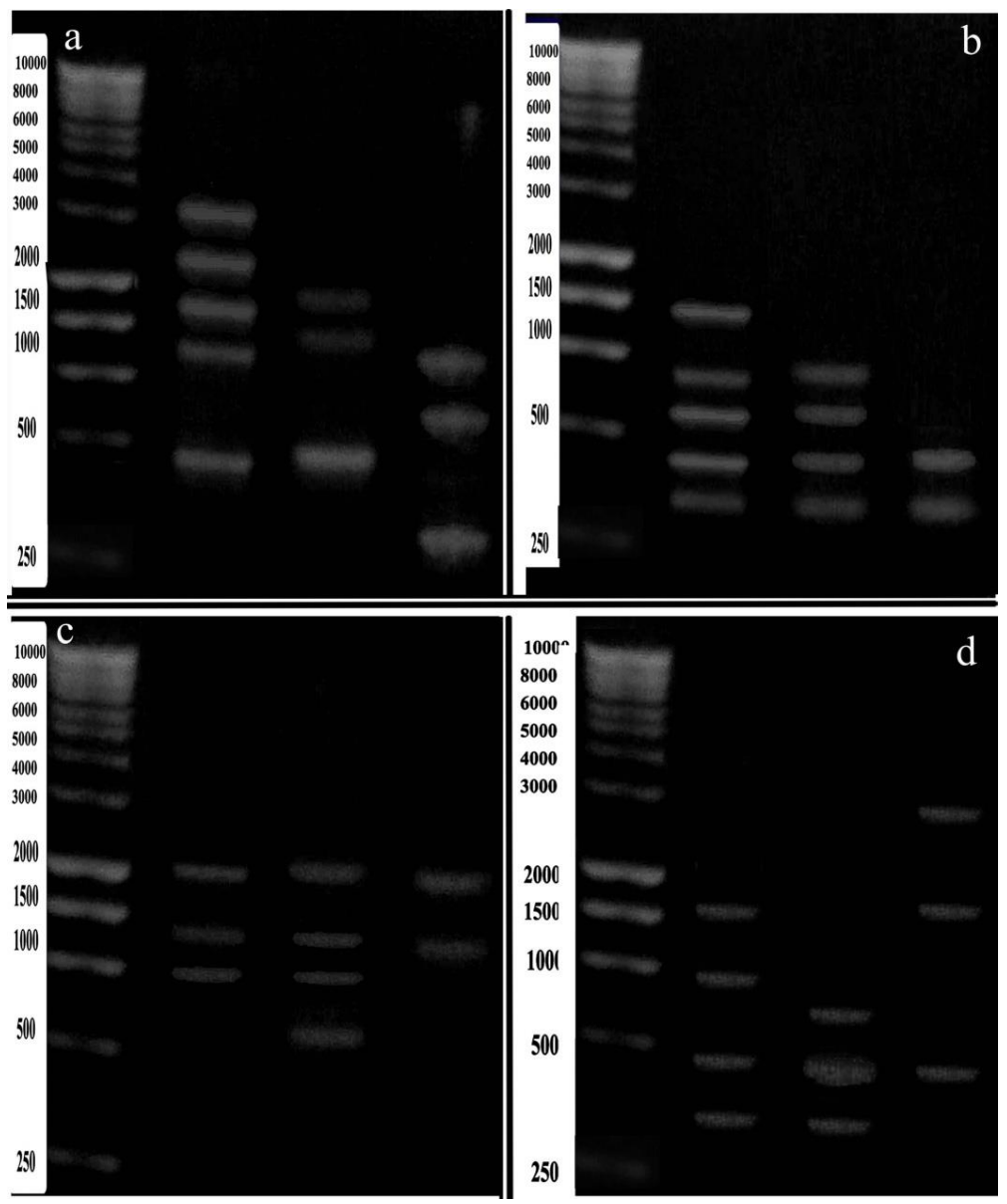

Fig. 1: RAPD-PCR pattern resulting from amplification of genomic DNA of $P$. gossipiella males. a: Primer V12; b: Primer U10; c: Primer E2; d: Primer A1 
The similarity index (SI) was 0.25 and 0.75 between the control and both of the samples irradiated with 50 and $150 \mathrm{~Gy}$, respectively. Such SI between both of the irradiated samples reached 0.33 using V12 primer (table 5).

Using U10 primer, 4 common bands between the control and 50Gy irradiated groups were obtained (figure 1b), their MS were 781, 548, 367, and 287. While there were 2 common bands between the control and 150Gy irradiated groups with average MS 376 and 287.

The SI between the control and the 50Gy irradiated group reached 0.89 while such SI with the $150 \mathrm{~Gy}$ irradiated group was 0.57 . The SI between the 50 and $150 \mathrm{~Gy}$ irradiated groups reached 0.67 (table 5).

Table 5: Similarity index among $P$. gossipiella adult males DNA pattern using UPGAMA (Dice) method by four primers:

\begin{tabular}{|c|c|c|c|}
\hline & $150 \mathrm{~Gy}$ & 50Gy & Control \\
\hline \multicolumn{4}{|c|}{$\mathrm{V} 12$} \\
\hline 150Gy & 1 & 0.33 & 0.25 \\
\hline 50Gy & & 1 & 0.75 \\
\hline Control & & & 1 \\
\hline \multicolumn{4}{|c|}{ U10 } \\
\hline 150Gy & 1 & 0.67 & 0.57 \\
\hline 50Gy & & 1 & 0.89 \\
\hline Control & & & 1 \\
\hline \multicolumn{4}{|c|}{$\mathbf{E} 2$} \\
\hline 150Gy & 1 & 0.67 & 0.8 \\
\hline $50 G y$ & & 1 & 0.86 \\
\hline Control & & & 1 \\
\hline \multicolumn{4}{|c|}{ A1 } \\
\hline 150Gy & 1 & 0.57 & 0.57 \\
\hline $50 G y$ & & 1 & 0.5 \\
\hline Control & & & 1 \\
\hline
\end{tabular}

Figure (1c) showed the comparison of DNA pattern between the unirradiated and irradiated pupae $(50,150 \mathrm{~Gy})$ using an E2 primer. Common bands with MS 2827, 1638 and 1425 were produced in both control and 50Gy irradiated groups while 2 common bands between control and 150Gy irradiated groups were present with MS 2827 and 1638.

The SI between both the control and 50Gy irradiated samples, from one side and the control and 150Gy irradiated groups on the other side reached 0.86 and 0.8 , respectively. Such index between both of the irradiated groups was 0.67 (table 5).

Two common bands were obtained using A1 primer between the control and 50Gy irradiated pupae and the control and 150Gy irradiated groups with MS (450 and 312) and (1588 and 450), respectively (figure 1d).

Table (5) shows that the SI between the control and 150Gy irradiated group, from one side and between the both irradiated groups was 0.57 while such SI reached 0.5 between the control and 50Gy irradiated groups using A1 primer.

\section{DISCUSSION}

The main role of essential trace minerals is to control and provide the proper activity of many enzymatic or biochemical reactions, numerous metabolic interactions between essential (or dietary) minerals and toxic elements may decrease risks caused by toxic metals. This may be due to the fact that both essential and toxic metals have common chemical properties ${ }^{18}$. 
All chemical elements that occur in excessive quantities act as stressful stimuli for a living organism. The minor elements, especially active or toxic ones, play a special role in metabolism and specific synergistic or antagonistic interactions. Such interaction results from the fact that ions with the same charge can alter each other's effect. Therefore, coexistence and concentration of other ions may affect the biological role of a particular ion. This may lead to the disturbance of the chemical balance in the organism, which then causes unexpected biological effects ${ }^{19}$.

The present study illustrated that the elements composition of unirradiated males was $\mathrm{K}, \mathrm{Mg}, \mathrm{Ca}, \mathrm{P}, \mathrm{Cu}, \mathrm{Zn}$ and $\mathrm{Cd}$. The obtained results revealed that the percentage of the elements varied according to the dose of gamma irradiation applied and it was obvious that $\mathrm{K}$ is the most major element in unirradiated and irradiated adults' males, this result agrees with Haiba \& El- Halafawy ${ }^{20}$ on Phthorimaea operculella, Rizk ${ }^{13}$ on Galleria mellonella and Abassy ${ }^{21}$ on Corcyra Cephalonica.

The high level of potassium may be related to its importance in the osmotic regulation of the blood and conductivity of the muscle membrane ${ }^{22}$.

In the current study, the concentration of $\mathrm{K}, \mathrm{Cu}, \mathrm{Zn}$ and $\mathrm{Cd}$ was raised in males irradiated as pupae with 50 and 150Gy. On the other hand, $\mathrm{Mg}, \mathrm{Ca}$ and $\mathrm{P}$ concentration was reduced due to pupal irradiation.

The concentration of several active major and trace elements can be used as effective biological indicators of acute radiosensitivity on a species level ${ }^{23}$, and the change in the elements concentrations might be due to the effect of ionizing radiation on the linkage between the chemical compounds, which led to breakage or aggregation of bonds.

The results of our study revealed that $\mathrm{Mg}$ concentrations decreased as the radiation dose increased. It was reported that $\mathrm{Mg}$ ions are essential to all cells as they are important to the basic nucleic acid. They catalyze enzymes using or synthesizing ATP ${ }^{24}$.

The decrease in calcium concentration is incompatible with Mohamed \& Ghareib ${ }^{12}$ on Ephestia cautella. This decrease may attribute to the calcium role in regulating power output of stretch and the indirect role flight muscles (A-IFMs) that are specialized to generate high mechanical power at fast contraction frequencies ${ }^{25}$.

The present results recorded an increase in copper concentration in adults after pupal irradiation. This finding agreed with Abassy ${ }^{21}$ on Corcyra Cephalonica. The reason of that increase may be due to the breaking effect of gamma radiation on tyrosine, melanin, and hemocyanine. As, Chapman ${ }^{22}$ stated that copper is the persistent metallic element constituted of tyrosine, melanin, and hemocyanin, which is copperprotein complex in the hemolymiph functioning like hemoglobin as in oxygen carrier.

It is well known that inorganic phosphorus is used to transport cellular energy in the form of adenosine triphosphate (ATP) ${ }^{26}$, which clarify the decrease in phosphorus concentration in the current study.

The resultant decrease in phosphorus concentration as revealed in our results might contribute to the changes occurred in DNA pattern in RAPD-PCR since it comprises a crucial element in its formation, which explains the radiosensitivity of DNA and RNA.

RAPD is a PCR-based molecular marker that is sensitive, effective, cheap and relatively simple as it amplifies the DNA damage after exposure to any physical and chemical agents ${ }^{27}$. Detection of genotoxic effects using this technique involves the comparison of banding profiles obtained from control and exposed DNA ${ }^{28}$. The study of the DNA pattern of normal adults and adults, previously irradiated as pupae, showed variations between them.

The appearance of some extra bands and disappearance of others, as a result of irradiation, were recorded throughout our investigation causing the variations in the 
PCR pattern among the different samples. This agreed with Hamed et al. ${ }^{29}$ and Elsaid ${ }^{30}$. The variations in the PCR patterns depend on the primer used, the dose of gamma irradiation given to the insect. The loss of the bands may be related to single and double-strand breaks, modified bases, oxidized bases, and point mutations induced by gamma radiation ${ }^{31}$. The appearance of new bands may indicate changes in some oligonucleotide priming sites due to mutations or conformational DNA changes ${ }^{32}$.

Ionizing radiation induces cytotoxic and mutagenic effects which are due to the genetic damage which may be caused during or immediately after transfer of radiation energy to genomic DNA certain characteristics as, (1) the damage by shortlived reactive oxygen species (ROS) and $\left(\mathrm{OH}^{-}\right)$generated by the radiolysis of water; (2) the damage due interaction of DNA with radiation; (3) mutations are set on genome replication ${ }^{8}$. DNA damage induced by ROS can result in single- or doublestrand breakage, modification of bases, modification of deoxyribose, and DNA cross-linking. Some damages as cell death, DNA mutation, genomic instability and replication errors can occur if the oxidative DNA damage is not repaired prior to DNA replication ${ }^{33}$.

Ionizing radiations resulted in a dissociation of the histones from the chromatin, hence, the DNA in vivo is in the form of chromatin ${ }^{34}$. DNA damage is caused as a result of the reaction of the reactive radicals produced from the fragmentation of protein subunits with a small segment of the nucleic acid ${ }^{35}$. Inhibition of the enzymes required for DNA synthesis as DNA polymerase as well as DNA repair, after the exposure to ionizing radiation, may inhibit DNA synthesis. This could occur by random DNA-protein binding, binding of the DNA polymerase to the irradiated DNA prior to or during the initiation of DNA synthesis or binding of the polymerase to the irradiated DNA after initiation and further along the DNA chain, i.e., during elongation ${ }^{36}$. It was reported the repairable damage might become nonrepairable after a short time ${ }^{37}$.

\section{CONCLUSION}

It was concluded that gamma radiation-induced alteration in the adult Pectinophora gossypiella biosystem. It caused changing of the metal composition, appearance and disappearance of some DNA bands. Changes of the adult biosystems were increased as the radiation dose increased. So, the use of the gamma radiation could cause sterilization of $P$. gossypiella adult irradiated as mature pupae.

\section{REFERENCES}

1. Ahmed Z. Model farming saving cotton from Pink bollworm. Available at: http://www.Pakistan.com/english/advisory/saving.cotton.from.the.pink.bllworm.sht $\mathrm{ml} .2013$

2. Mohammed HF, Mikhaiel AA, Abul-Fadl HAA. Histopathological effects of Bacillus thuringiensis and gamma irradiation on $\mathrm{F}_{1}$ larvae of the greater wax moth, Galleria mellonella. Isotope Rad Res. 2006; 38(4):1373.

3. Henneberry TJ, Clayton E. Effects of Gamma Radiation on Pink Bollworm (Lepidoptera: Gelechiidae) Pupae: Adult Emergence, Reproduction, Mating, and Longevity of Emerged Adults and Their F1 Progeny. J Econ Entomol. 1988; 81(1): 322-326.

4. Lindqvist L. Individual and interspecific variation in metal concentrations infive species of bumble bees (Hymenoptera: Apidae). Environ Entomol. 1993; 22(6):1355-1357. 
5. Gilmour D. The metabolism of insects. Oliver \& Boyd, Edinburgh. 1965; 195pp.

6. El-Shall SS. Biological and biochemical studies on the gamma irradiation cotton leaf worm Spodoptera littoralis. Ph.D. Thesis, Faculty of Agriculture, Ain Shams University. PP $62-72$. https://theses.ju.edu.jo/Original_Abstract/JUF0442965/JUF0442965.pdf. 1991.

7. Kinipling EF. Possibilities of insect control or eradication through the use of sexually sterile males. J Econ Entomol. 1955; 48(3):459-462

8. Von Sonttag C. New aspects in the free-radical chemistry of pyrimidine nucleobases. Free Radical Res Commun. 1987; 2: 217-24.

9. Cenkci S, Yildiz M, Hakki-Cigerci I, Konuk M, Bozdag A. Toxic chemicalsinduced genotoxicity detected by random amplified polymorphic DNA (RAPD) in bean (Phaseolus vulgaris L.) seedlings. Chemosphere. 2009; 76: 900-906.

10. Enan MR. Application of random amplified polymorphic DNA to detect genotoxic effect of heavy metals. Biotech Appl Biochem. 2006; 43: 147-154.

11. Lanzone V, Tofalo R, Fasoli G, Perpetuini G, Suzzi G, Sergi M, Corrado F, Compagnone D. Food borne bacterial models for detection of benzo[a]pyreneDNA adducts formation using RAPD-PCR. Microb Biotechnol. 2016; 9(3): 400-407. 12. Mohamed HF, Ghareib OH. Biochemical and Biological Effects of Gamma Irradiation on Certain Mineral Contents in the Almond Moth Tissues, Ephestia Cautella (Walker). Isotope Rad Res. 2009; 41(4): 1533-1550.

13. Rizk SA. Changes of Elemental Composition Induced by Gamma Radiation between Parents and First Generation of the Greater Wax Moth, Galleria Mellonella L. J Rad Res Appl Sci. 2008; 1(1): 26-34

14. Abd El-Hafez A, Metwally AG, Saleh MRA. Rearing pink bollworm Pectinophora gossypiella (Saund.) on kidney bean diet in Egypt. Res Bull, Fac Agric, Zagazig Univ. 1982; 576: 1-10.

15. Williams JG, Kubelik AR, K. Livak J, Rafalski JA, Tingey SV. DNA Polymorphisms Amplified by Arbitrary Primers Are Useful as Genetic Markers. Nucleic Acids Res. 1990; 18(22): 6531-6535.

16. Black WC, Nancy MD, Gary JP, James RN, Jennifer MP. Use of the random amplified polymorphic DNA polymerase chain reaction (RAPDPCR) to detect DNA polymorphisms in aphids (Homoptera: Aphididae). Bull Entomol Res. 1992; 82(2): 151-159.

17. Nei M, Li WH. Mathematical model for studying genetic variation in terms of restriction endonucleases. PNAS, USA. 1979; 76(10):5269-5273.

18. Zaksas NP, Sultangazieva TT, Gerasimov VA, Determination of trace elements in bone by two-jet plasma atomic emission spectrometry. J Anal Bioanal Chem. 2008; 391: 687-693

19. Brodziak DB, Kwapulinski J, Kusz D, Gajda Z, Sobczyk K. Interactions between concentrations of chemical elements in human femoral heads. Arch. Environ Contam Toxicol. 2009; 57(1):203- 210.

20. Haiba IM, El-Halfawy NA. Influence of gamma- radiation on elemental composition of potato tuber moth, Phthorimaea operculella, Zeller. Egyptian J Appl Sci. 2000; 15 (10): 263-276.

21. Abassy SA. The Elemental Composition of Normal and Irradiated Rice Moth Corcyra Cephalonica (Staint) (Lepidoptera-Pyralidae). J Rad Res Appl Sci. 2012; 5(4): $769-780$.

22. Chapman RF. Insect Structure and Function. American Elsevier publishing Co., Inc., New York. 1973; pp 819.

23. Levy R., Cromroy HL. Concentration of some major and trace elements in fortyone species of adult and immature insects determined by atomic absorption spectroscopy. Ann Entomol Soc America. 1973; 66(3): 523-526. 
24. Romani AMP. Magnesium in Health and Disease. In Astrid Sigel; Helmut Sigel; Roland K. O. Sigel. Interrelations between Essential Metal Ions and Human Diseases. Metal Ions in Life Sciences. Springer. 2013; pp. 49-79.

25. Gordon $\underline{S}$, Dickinson MH. Role of calcium in the regulation of mechanical power in insect flight. PNAS, USA. 2006; 103(11): 4311-4315.

26. Greenwood NN, Earnshaw A. Chemistry of the Elements $\left(2^{\text {nd }} E d n.\right)$. Butterworth -Heinemann, Pergamon Press, Oxford. 1997; pp. 473-546.

27. Zhou L, Li J, Lin X, Al-Rasheid KAS. Use of RAPD to detect DNA damage induced by nitrofurazone in marine ciliate, Euplotes vannus (Protozoa, Ciliophora). Aquat Toxicol. 2011; 103:225-232.

28. Atienzar FA, Jha AN. The random amplified polymorphic DNA (RAPD) assay and related techniques applied to genotoxicity and carcinogenesis studies: a critical review. Mutat Res. 2006; 613: 76-102.

29. Hamed MS, Salama MS, Salem H, Abbassy SA, Zaghloul YS. Sterility and Associated Molecular Characteristics in Male Callosobruchus maculates. J Rad Res Appl Sci. 2009; 2(3): 563-575.

30.El-said TS. Inherited sterility in the cotton leaf worm Spodoptera littoralis, (Boisd.), and changes in the DNA pattern as a result of using gamma radiation. Ph.D. Thesis Fac. Sci. Ain Shams University. PP 216-219. http://www.iaea.org/inis/collection/NCLCollectionStore/_Public/46/066/46066344.p df. 2013.

31. Esnault MA, Legue F, Chenal C. Ionizing radiation: advances in plant response. Environ Exper Bot. 2010; 68: 231-237.

32. Dhakshanamoorthy D, Selvaraj R, Chidambaram AL. Induced mutagenesis in Jatropha curcas L. using gamma rays and detection of DNA polymorphism through RAPD marker. C R Biol. 2011; 334: 24-30.

33. Valko M, Rhodes CJ, Moncol J, Izakovic M, Mazur M. Free radicals, metals and antioxidants in oxidative stress-induced cancer. Chem Biol Interact. 2006; 160: 140.

34. Mee LK, Weiss JJ, Wheeler CM. Enhancement of template activity of calf Thymus and rat live chromatin by gamma. Rad Res.1973; 54(3): 539-485.

35. Werner MH, Clore GM, Fisher CL, Fisher RJ, Trinh L, Shiloach J, Gronenborg AM. The solution structure of the human ETSI-DNA complex reveals a novel made of leading and true side chain intercolation. Cell. 1995; 83:761-771.

36. Landbeck L, Hagen U. Action of DNA polymerasel on gamma irradiated DNA. Biochim Biophys Acta. 1973; 331(3): 318 - 327.

37. Engelmann F. The physiology of insect reproduction. Department of Zoology, University of California, Los Angeles, Oxford, Eng-Pergamon. 1972; pp. 307. 